\title{
Studies on Pathogenicity of Root-Knot Nematode, Meloidogyne incognita on Turmeric
}

\author{
K.J. Niranjana Prabhu ${ }^{1 *}$, V. Kantharaju ${ }^{1}$, N. Thammaiah ${ }^{2}$, \\ Y.S. Mahesh ${ }^{3}$ and T.N. Pushpa ${ }^{1}$
}

${ }^{1}$ K. R. C College of Horticulture, Arabhavi, Karnataka, India

${ }^{2}$ College of Horticulture, Mysuru, Karnataka, India

${ }^{3}$ College of Horticulture, Bagalkot, Karnataka, India

*Corresponding author

\section{A B S T R A C T}

Keywords

Turmeric,

Pathogenicity,

Meloidogyne

incognita

Article Info

Accepted:

10 December 2017

Available Online:

10 January 2018
Root-knot nematode (Meloidogyne spp.) is one of the major problem, which causes galls/knots in the rhizomes and causes considerable yield loses. A pot study was conducted to assess the pathogenicity of Meloidogyne incognita on turmeric at different inoculum densities $\left(0,10,100,1000,5000\right.$ and $10000 \mathrm{~J}_{2}$ per pot). The progressive reduction in growth and yield parameters with the increasing inoculum levels of $M$. incognita was observed. However, plant height of $44.33 \mathrm{~cm}$ was recorded in plants inoculated with 10000 $\mathrm{J}_{2}$ per pot as against maximum of $69.67 \mathrm{~cm}$ in plants inoculated with $10 \mathrm{~J}_{2}$ per plant. The least rhizome fresh weight $(181.00 \mathrm{~g})$ and dry weight $(35.67 \mathrm{~g})$ was recorded in plants inoculated with $10000 \mathrm{~J}_{2}$ per pot. The soil nematode was highest in plants inoculated with $5000 \mathrm{~J}_{2}$ per pot (3610) followed by $10000 \mathrm{~J}_{2}$ per pot (2660) and least in pots inoculated with $10 \mathrm{~J}_{2}$ per pot (95.33). The highest number of galls per plant was observed in plants inoculated with $10000 \mathrm{~J}_{2}$ per pot (107.33) followed by $5000 \mathrm{~J}_{2}$ per pot (101.33). Reduction in growth and yield parameters and increase in number of galls was observed with increase in inoculum levels of $M$. incognita.

\section{Introduction}

Turmeric (Curcuma longa L.) is one of the important spice crops grown in India since the times immemorial. It is an herbaceous perennial plant, native to tropical south-east Asia belonging to the family Zingiberaceae. It is regarded as a symbol of well-being and future and is widely used in ceremonies and religious functions. It is known as 'haridra' meaning yellow coloured wood in Sanskrit and is a part of Indian delicacies, health care as well as rites and rituals since time immemorial. The anti-oxidant attributes of this spice protect against the high energy free radical damage to organic cells (Maheshwari et al., 2006). It is cultivated for its underground rhizomes which are used in many ways $v i z$, condiment in culinary preparation, coloring agent in textiles, as food and confectioneries. Medicinally, it acts as carminative, antiseptic and antiparasitic for many skin infections. It cures the sore throat, 
common cold and used as an appetizer and helps in digestion. It is also used in the preparation of cosmetics, soaps, skin ointments and tooth pastes.

The studies on pathogenicity are important to know minimum population causing root-knot infection, which will be helpful in maintaining the population below the economic threshold level. Nematode management is basically centered on prevention. This is because once a plant is parasitized, it is extremely difficult to eradicate the nematode without destroying the host plant.

\section{Materials and Methods}

The plants of turmeric cv. Salem were raised in earthen pots filled with sterilized soil. The plants were inoculated after 45 days of planting by making four holes around the base of the plant $(2.5 \mathrm{~cm}$ depth and $2 \mathrm{~cm}$ away from the base). Different quantities of the nematode suspension having a concentration of 100 juveniles per $\mathrm{ml}$ was carefully inoculated to plants by pouring into the holes depending upon the number of larvae required to be inoculated i.e., $0.1 \mathrm{ml}, 1 \mathrm{ml}, 10 \mathrm{ml}, 50 \mathrm{ml}$ and $100 \mathrm{ml}$ in order to inoculate 10, 100, 1000, 5000 and 10000 juveniles, respectively. A set of plants were kept without nematode inoculation which served as control. Three replications were maintained for each treatments and the plants were watered twice a week and weeding was done when necessary.

Six months after inoculation, the plants were carefully depoted and the roots were washed free of soil under gently running water. The observations were recorded with respect to plant growth like plant height $(\mathrm{cm})$, number of tillers, number of leaves, yield per plant and nematodes observations like soil nematode population, number of galls/root system and number of egg mases/root system was recorded.

\section{Results and Discussion}

The data on pathogenicity of root-knot nematode, $M$. incognita on growth and development of turmeric cv. Salem presented in Table 1 and 2, Figures 1, 2, 3 and 4.

The different inoculum levels of $M$. incognita on turmeric cv. Salem revealed the variation in number of leaves. The number of leaves produced was highest (16.67) at zero inoculum level followed by $10 \mathrm{~J}_{2}$ per plant (15.33). But the number of leaves decreased with increase in inoculum level and was least (8.33) in $10000 \mathbf{J}_{2}$ per plant which was followed by $5000 \mathrm{~J}_{2}$ per plant (9.66). Population of $M$. incognita at different densities resulted in progressive reduction in the height of plants at both 90 and 180 days after inoculation (DAI).

However, plant height of 28.60 and 44.33 was recorded in plants inoculated with $10000 \mathrm{~J}_{2}$ per pot as against 46.33 and $69.67 \mathrm{~cm}$ was observed in plants inoculated with $10 \mathrm{~J}_{2}$ per plant respectively. The fresh and dry weight of shoot was decreased with increase in inoculum levels of $M$. incognita. The fresh and dry weight of shoot was minimum in plants inoculated with $10000 \mathrm{~J}_{2}$ per pot (9.33 and $18.40 \mathrm{~g})$. However the maximum fresh and dry weight of shoot was recorded in plant inoculated with $10 \mathrm{~J}_{2}$ per pot (143.00 and $28.67 \mathrm{~g}$ ) followed by $100 \mathrm{~J}_{2}$ per pot (138.66 and $26.90 \mathrm{~g}$ ). Reduction in fresh and dry weight of rhizome with increasing inoculum levels of $M$. incognita was noticed. The highest fresh and dry weight of rhizome was recorded in plants inoculated with $10 \mathrm{~J}_{2}$ per pot (269.00 and $53.10 \mathrm{~g}$ ) as against least in plants inoculated with $10000 \mathrm{~J}_{2}$ per pot (181.00 and $35.67 \mathrm{~g})$. Maximum reduction was seen in plants inoculated with $10,000 \mathrm{~J}_{2}$ per pot and this was in accordance with the findings of Mahalik and Sahoo (2016) and Kantharaju (1999). Plants inoculated with 
1000 or more nematodes the plant growth was significantly reduced in cucumber (Krishnaveni and Subramanian, 2003). Darekar and Bele (1990) also reported > 500 $\mathbf{J}_{2}$ per plant resulted in suppression of shoot and root growth. Poornima and Sivagami (1998) also reported that an initial level of $>5000 \mathrm{M}$. incognita larvae per plant was highly pathogenic to turmeric. When turmeric plants were inoculated with $M$. incognita and $R$. reniformis, significant reductions in both growth and yield were observed individually at the rate of 1000 juveniles per plant (Haidar et al., 1998).

The number of galls increased with increase in inoculum levels of $M$. incognita. However the highest number of galls per plant was observed in plants inoculated with $10000 \mathrm{~J}_{2}$ per pot (107.33) followed by plants inoculated with $5000 J_{2}$ per pot (101.33). The plants inoculated with 1000 and $100 \mathrm{~J}_{2}$ per pot recorded 33.33 and 18.33 galls per plant respectively and lowest number of galls (8.33) was recorded in plants inoculated with $10 \mathrm{~J}_{2}$ per pot. The highest number of egg masses was observed in plants inoculated with 10000 $\mathrm{J}_{2}$ per pot (101.67). The plants inoculated with 5000 and $1000 \mathrm{~J}_{2}$ per pot recorded 89.00 and 38.33 egg mass per plant respectively as against minimum (5.33) in plants inoculated with $10 \mathrm{~J}_{2}$ per pot. The highest nematode population in soil was observed in plants inoculated with $5000 \mathrm{~J}_{2}$ per pot (3610.00) followed by plants inoculated with $10000 \mathrm{~J}_{2}$ per pot (2660.00). Plants inoculated with 1000 and $100 \mathrm{~J}_{2}$ per pot showed population of 1959.67 and 203.33 respectively in soil as against the lowest nematode population (95.33) in plants inoculated with $10 \mathrm{~J}_{2}$ per pot.

Table.1 Effect of different inoculum levels of root-knot nematode, $M$. incognita on growth and yield parameters of turmeric

\begin{tabular}{|c|c|c|c|c|c|c|c|c|}
\hline \multirow{2}{*}{$\begin{array}{c}\text { Inoculum } \\
\text { level } \\
\left(\mathbf{J}_{2} / \text { plant }\right)\end{array}$} & \multirow{2}{*}{$\begin{array}{c}\text { No. of } \\
\text { leaves/pl } \\
\text { ant }\end{array}$} & \multirow{2}{*}{$\begin{array}{c}\text { No. of } \\
\text { tillers/pl } \\
\text { ant }\end{array}$} & \multicolumn{2}{|c|}{$\begin{array}{l}\text { Plant height } \\
\text { (cm) }\end{array}$} & \multicolumn{2}{|c|}{ Shoot weight (g) } & \multicolumn{2}{|c|}{$\begin{array}{l}\text { Rhizome weight } \\
\text { (g) }\end{array}$} \\
\hline & & & $\begin{array}{c}90 \\
\text { DAI }\end{array}$ & $\begin{array}{c}180 \\
\text { DAI }\end{array}$ & Fresh & Dry & Fresh & Dry \\
\hline 0 & 16.67 & 3.67 & 48.33 & 75.33 & 148.67 & 29.57 & 281.00 & 55.60 \\
\hline 10 & 15.33 & 3.00 & 46.33 & 69.67 & 143.00 & 28.67 & 269.00 & 53.10 \\
\hline 100 & 13.66 & 3.33 & 44.00 & 66.33 & 138.66 & 26.90 & 260.00 & 56.17 \\
\hline 1000 & 11.33 & 2.67 & 39.33 & 59.33 & 122.66 & 23.83 & 227.66 & 45.83 \\
\hline 5000 & 9.66 & 2.00 & 34.00 & 51.00 & 110.00 & 21.83 & 191.66 & 37.90 \\
\hline 10000 & 8.33 & 2.00 & 28.60 & 44.33 & 90.33 & 18.40 & 181.00 & 35.67 \\
\hline S.Em \pm & 0.40 & NS & 1.66 & 2.30 & 4.01 & 0.82 & 8.43 & 1.47 \\
\hline CD@ 5\% & 1.25 & & 5.11 & 7.10 & 12.37 & 2.53 & 26.00 & 4.52 \\
\hline
\end{tabular}

*DAI- days after inoculation

*Replications: 3 
Table.2 Effect of different inoculum levels of root-knot nematode, $M$. incognita on population densities of nematode in turmeric

\begin{tabular}{|c|c|c|c|c|c|c|}
\hline $\begin{array}{l}\text { Inoculum } \\
\text { level } \\
\left(\mathbf{J}_{2} / \text { plant }\right)\end{array}$ & $\begin{array}{l}\text { No. of } \\
\text { galls/ } \\
\text { root } \\
\text { system }\end{array}$ & $\begin{array}{c}\text { Gall } \\
\text { Index }\end{array}$ & $\begin{array}{l}\text { No. of egg } \\
\text { masses/ root } \\
\text { system }\end{array}$ & $\begin{array}{l}\text { Egg } \\
\text { mass } \\
\text { Index }\end{array}$ & $\begin{array}{c}\text { Soil } \\
\text { nematode } \\
\text { population } \\
\text { (200 cc soil) }\end{array}$ & $\begin{array}{l}\text { Root nematode } \\
\text { population } \\
(\mathbf{1 0} \mathbf{g})\end{array}$ \\
\hline 0 & 0.00 & 0 & 0.00 & 0 & 0.00 & 0.00 \\
\hline 10 & 8.33 & 2 & 5.33 & 2 & 95.33 & 29.00 \\
\hline 100 & 18.33 & 3 & 12.67 & 3 & 203.33 & 90.00 \\
\hline 1000 & 33.33 & 4 & 38.33 & 3 & 1959.67 & 103.00 \\
\hline 5000 & 101.33 & 5 & 89.00 & 4 & 3610.00 & 191.00 \\
\hline 10000 & 107.33 & 5 & 101.67 & 5 & 2660.00 & 236.66 \\
\hline S.Em \pm & 1.79 & - & 2.59 & - & 251.23 & 14.57 \\
\hline CD@ 5\% & 5.51 & - & 7.97 & - & 774.14 & 44.90 \\
\hline
\end{tabular}

*Replications: 3

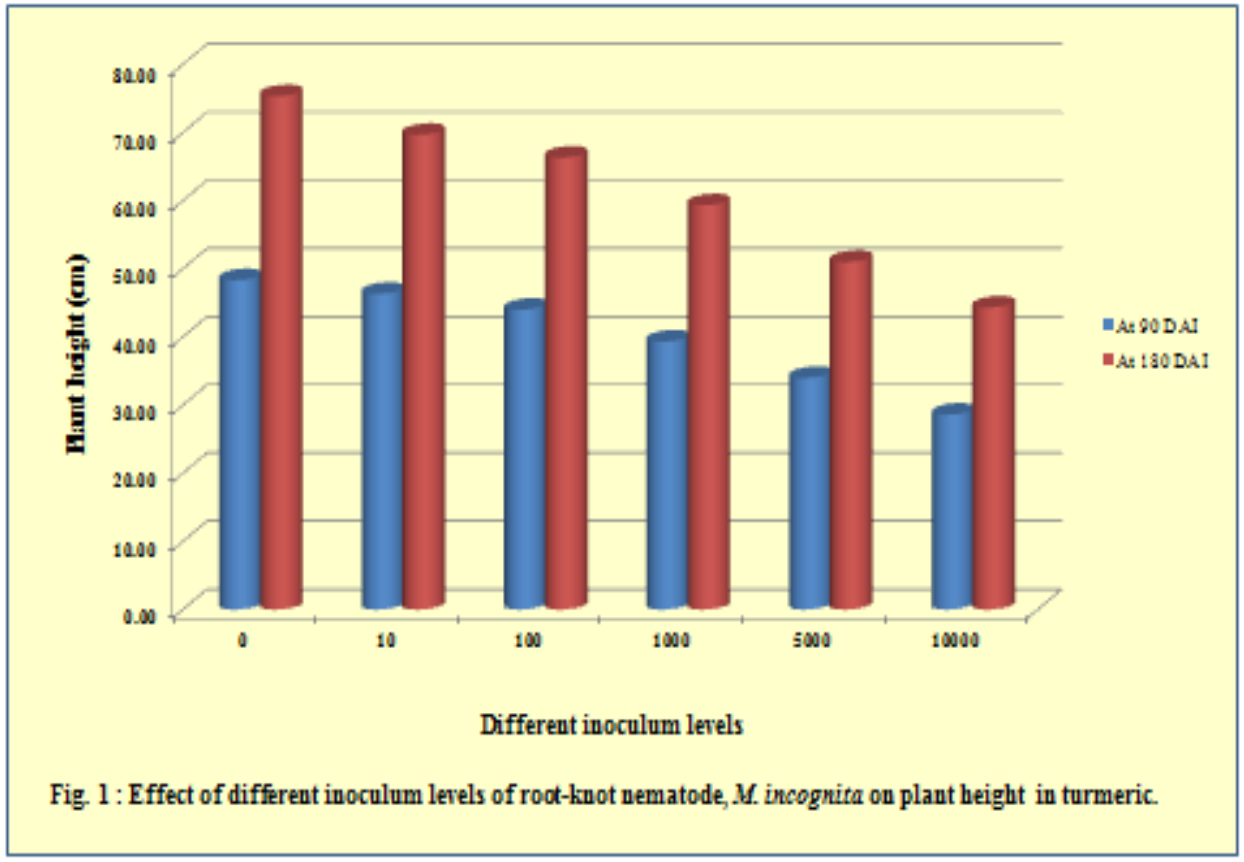




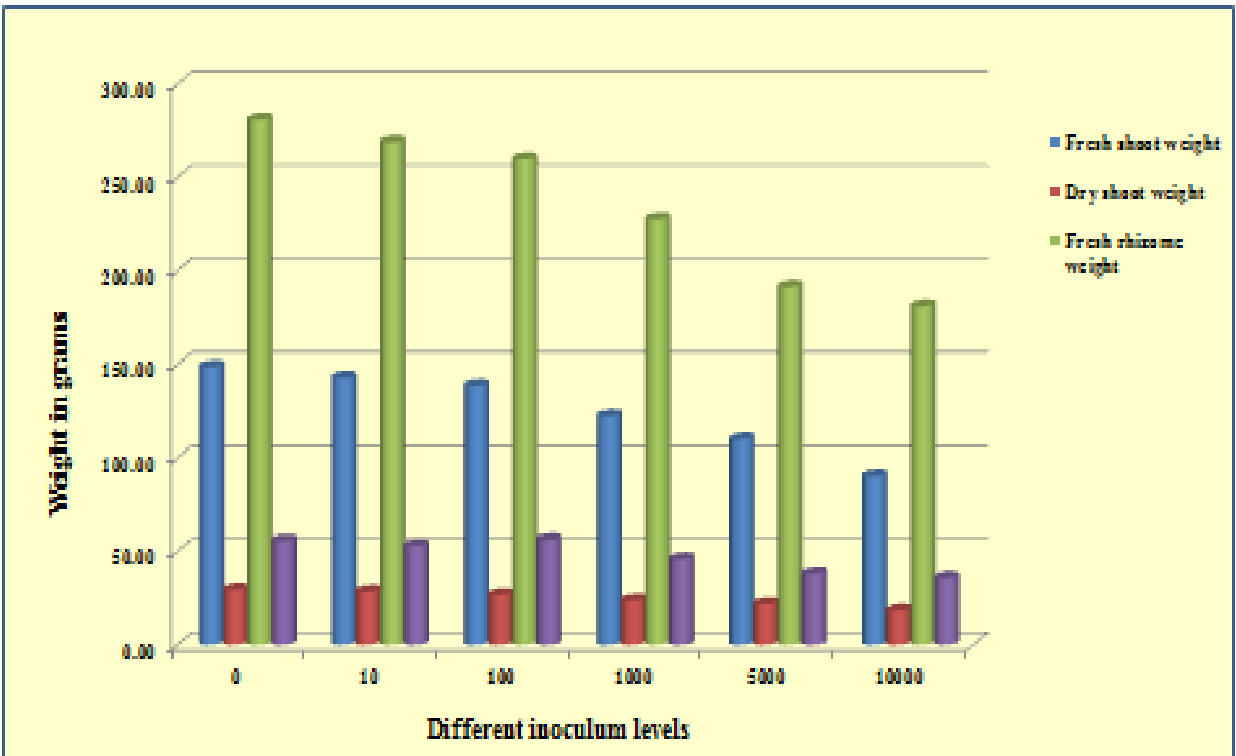

Fig. 2 : Effect of different inoculum levels of root-knot nematode, M. incognita on fresh and dry weight of shoot and rhizome in turmeric.

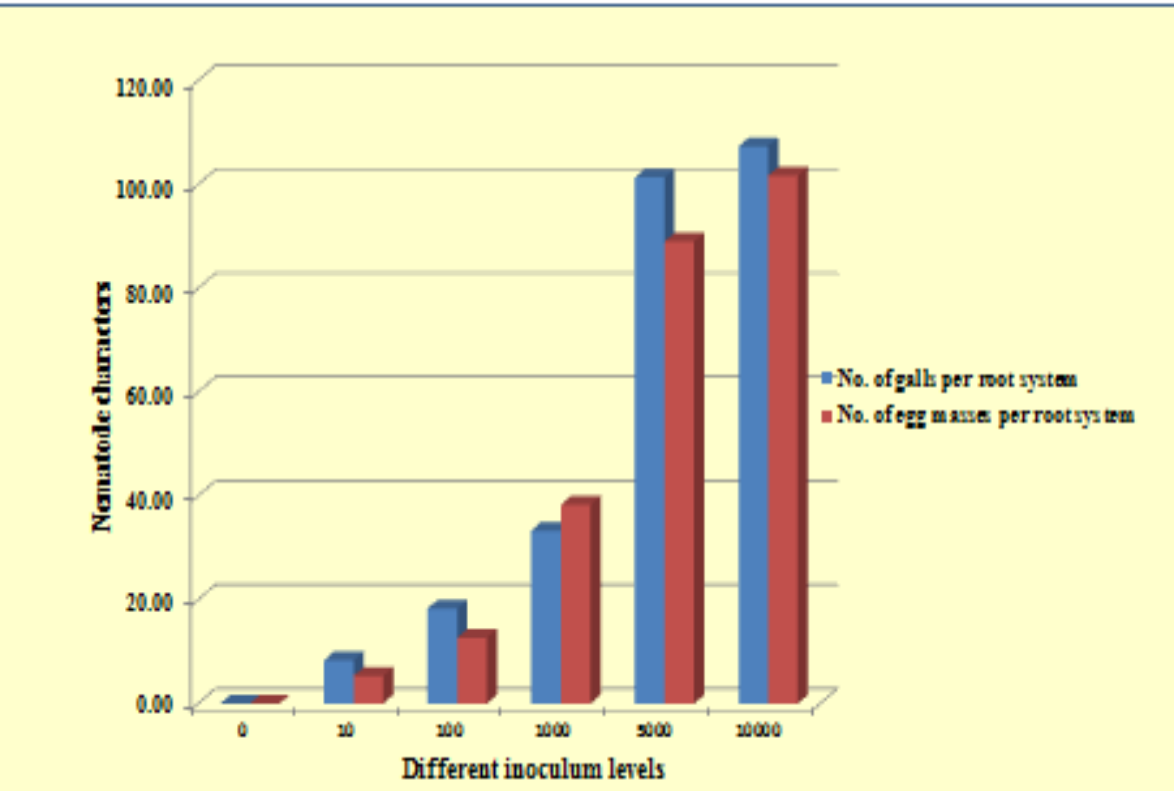

Fig. 3: Effect of different inoculum levels of root-knot nematode, M. incognita on number of galls and egg masses per root system in turmeric. 


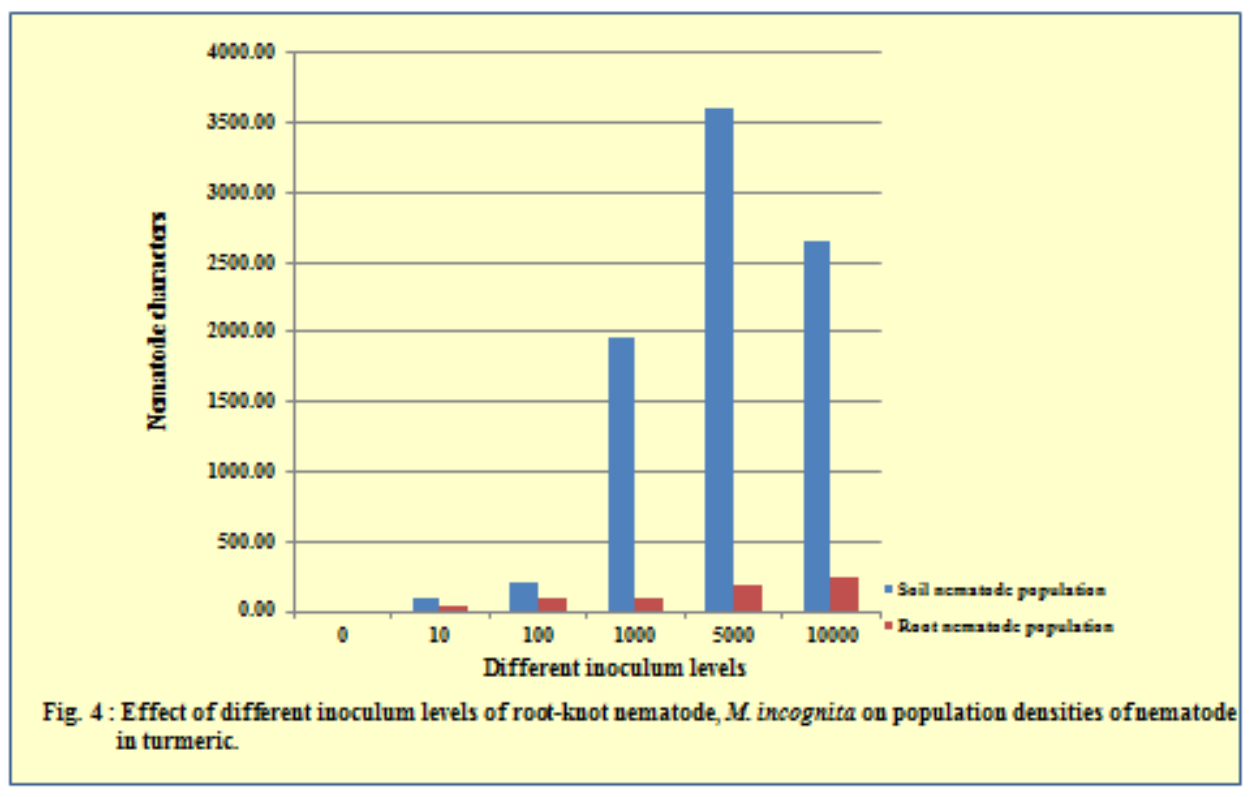

The plants inoculated with $10 \mathrm{~J}_{2}$ per pot recorded lowest root nematode population (29.00) and highest in $10000 \mathrm{~J}_{2}$ per pot (236.66). Plants inoculated with 100 and 1000 $\mathrm{J}_{2}$ per pot recorded the root nematode population of 90.00 and 103.00 respectively. In the present studies, the increaseing inoculum levels of $M$. incognita were found to reduce the growth and yield of the host by way of reducing the number of leaves, plant height (90 and $180 \mathrm{DAI}$ ), fresh weight of shoot, dry weight of shoot, fresh weight of rhizome and dry weight of rhizome.

The yield parameters viz., fresh and dry weight of rhizome decreased with the increasing inoculum levels of $M$ incognita. Highest reduction of rhizome weight was observed in plants inoculated with $10000 \mathrm{~J}_{2}$ per pot $(181.00$ and $35.67 \mathrm{~g})$ followed by plants inoculated with $5000 \mathrm{~J}_{2}$ per pot (191.66 and $37.90 \mathrm{~g}$ ) and minimum reduction was recorded in plants inoculated with $10 \mathrm{~J}_{2}$ per pot (269.00 and 53.10) followed by plants inoculated with $100 \mathrm{~J}_{2}$ per pot (260.00 and $56.17 \mathrm{~g})$.
Poornima and Sivagami (1998) also reported that an initial level of $>5000 \mathrm{M}$. incognita larvae per plant was highly pathogenic to turmeric. The nematode population in soil increases with increase in inoculum levels as well as nematode reproduction rate was inversely proportional to the nematode inoculum level and this might be due to competition of nematodes for host penetration, food and space.

Lesser are the nematodes, lesser is the competition and therefore more nematodes reduced the reproductive rate (Sumitha, 2014). The highest gall index and egg masses were also recorded at inoculums levels of 1000 and 10000 respectively (Krishnaveni and Subramanian, 2003; Mahalik and Sahoo, 2016).

The nematode population in root increased significantly with increase in inoculum levels of $M$. incognita. Highest nematode population was observed in plants inoculated with 10,000 $\mathrm{J}_{2}$ per pot. The plants inoculated with $10 \mathrm{~J}_{2}$ per pot showed lowest nematode population. 


\section{References}

Darekar, K. S. and Bele, P. P., 1990. Reaction of cucumber cultivars and lines to rootknot nematode. Inter. Nematol. Network Newsl., 7(2): 13-14.

Haidar, M. G., Jha, R. N. and Nath, R. P., 1998. Studies on the nematodes of spices, pathogenicity effect of root-knot (Meloidogyne incognita) and reinform nematodes (Rotylenchulus reinforms) alone and in combination on turmeric (Curcuma longa L.). Indian J. Nematol., 28: 52-55.

Kantharaju, V., 1999. Studies on plant parasitic nematodes associated with potato in Karnataka. M.Sc thesis, Uni. Agric. Sci. Bangalore (India).

Krishnaveni, M. and Subramanian, S., 2003. Pathogenicity of Meloidogyne incognita on cucumber (Cucumis sativus L.). Proceedings of National Symposium on Biodiversity and Management of Nematodes in Cropping Systems for Sustainable Agriculture, Jaipur, India,11-13-November, 2002-2003; 89-92.

Mahalik, J. K and Sahoo, N. K., 2016. Effect of inoculum density of root-knot nematode (Meloidogyne incognita) on okra (Abelmoschus esculentus L.), Internat. J. Plant Protec., 9(2): 603607.

Maheshwari, R. K., Singh, A. K., Gaddipati, J. and Srimal, R. C., 2006. Multiple biological activities of curcumin: a short review. Life Sci., 78: 2081-2087.

Poornima, K., Sivagami, V., 1998. Pathogenicity of Meloidogyne incognita of turmeric (Curcuma longa L.). In: Mehta, U.K (Ed.), Nematology: Challenges and Opportunities in 21st Century. Proceedings of the Third International Symposium of Afro-Asian Society of Nematologists (TISAASN) Afro-Asian Society of Nematologists, Luton. April 16, Coimbatore. Pp. 29-30.

Poornima, K., Sivagami, V., 1999. Occurrence and seasonal population behavior of phytone-matodes in turmeric (Curcuma longa L.). Pest Manage Hort. Ecosyst. 5: 42-45.

Sumitha, K., 2014. Pathogenicity of root-knot nematode, Meloidogyne incognita in green gram, Int. J. Pure App. Biosci., 2(6): 2320-7051.

\section{How to cite this article:}

Niranjana Prabhu, K.J., V. Kantharaju, N. Thammaiah, Y.S. Mahesh and Pushpa, T.N. 2018. Studies on Pathogenicity of Root-Knot Nematode, Meloidogyne incognita on Turmeric. Int.J.Curr.Microbiol.App.Sci. 7(01): 942-948. doi: https://doi.org/10.20546/ijcmas.2018.701.113 